\title{
Investor Sentiment Measurement of Merger and Acquisition Companies in Indonesia
}

\author{
${ }^{*}$ N. A. Rizal ${ }^{1,2}$, D. P. Koesrindartoto ${ }^{1}$ \\ ${ }^{1}$ Institut Teknologi Bandung, Indonesia \\ 2Institute Management Telkom Bandung, Indonesia \\ *Nora.amelda@sbm-itb.ac.id
}

\begin{abstract}
This research is conducted about how to measure the investor sentiment, when the prospects of merger or acquisition have completed. The measurement is done by examining the likelihood of success or failure, which can determine the investment strategy, while holding a target when it is still occurred. It is to see whether the positive investor sentiment should increase or decrease when the probability of the acquisition's success increases or decreases and that sentiment will also vary with events during the period of offering. The purpose of this paper is to make a probability model that will describe about the investor sentiment behavior during the merger and acquisition process in Indonesia. This model will also separate the effect of Indonesia markets and target company's movement. The samples are taken from the companies that listed in Jakarta Stock Exchange from 2009 and 2012. The information that we used in this research is the public news from the Regulator Committee of Business Providers (Komite Penyelenggara Pengawasan Usaha/KPPU) and the available newspaper in Indonesia. The result shows that after the first announcement, the investor sentiment react very enthusiasm and the trend line of the sentiment tend to increase against the stock price and the market.
\end{abstract}

Keywords: Investor Sentiment, Behavioral Finance, Probability Model, Merger \& Acquisition, Indonesian Companies

\section{Introduction}

People will react when they heard about news or information, whether it is good or bad. This behavior is very normal to the most of people. Investor also tends to react to the financial market when they heard news. This behavior will influence their conduct to their investment. In traditional finance, the behavior of the investor is assumed as a rationale and unemotional people. But in reality, investor will react irrational and emotional; this reaction is called as investor sentiment.

The study of investor sentiment has been recently discussed in behavioral finance field. These studies are done among other things by Black (1986), De Long et al. (1990) and Barberis et al. (1998) , who made models to describe the relationship between investor's sentiment and price of assets; Lee et al. (1991), Neal \& Wheatley (1998) and Brown \& Cliff (2004), they identify direct and indirect sentiment measurement (Daniel et al., 2001). Bernanke \& Kuttner (2005), who studied overreaction that caused by the surprise policy action which affect stock prices to monetary shocks; Solt \& Statman (1988), Brown \& Cliff (2005), Kumar \& Lee (2006) and Baker \& Wurgler (2006, 2007), who found indication that stock prices are moved by the investor sentiment and affects expected return; Brown \& Cliff (2005) and Kumar \& Lee (2006) shows that monetary news moved by the investor psychology.

Kurov (2010) shows that there are possible asymmetries affected by government policy in bull market and bear market. He found that policy decisions have less effect on stock return and sentiment in bull markets, than in bear market. In bear market, the policy decisions have a shocking effect on stock return and sentiment. They conclude that investor sentiment play an important role to the monetary shocks. Kurov (2010) also shows some evidence that there are also relationship between monetary news on stock market and investor sentiment. Kasper (2008) shows that investor sentiment can be modeled using the probability model, which can separate the target's movement from the market's movement. Under this model, he said that, one can make decision to continue or hold the process of merger or acquisition. 
This research examined the investor sentiment during the period of merger and acquisition offering in Indonesia, under the probability model of Kasper (Kasper, 2008). During the merger and acquisition process, we want to see whether the positive investor sentiment will increase or decrease and change their sentiment, following the increasing or decreasing probabilities. Our research will highlight the measurement of investor sentiment during the process of merger and acquisition in Indonesia that separated from the target's movement of merger or acquisition from the market's movement.

In the next section, we will explain more about the theory of probability model that is used by Kasper (2008). Further the description about data and methodology will be given. The next section, the results based on the sample, will be discussed. Finally, this paper will be closed with the conclusion and recommendation.

\section{Literature Review}

Many studies have been conducted for the effects after Merger and Acquisition process is done, but there are few studies about how the investors are playing their role into the price itself when they heard the announcement about merger and acquisition. Kasper (2008) has been studied about this. He made a probability model to see how the investor will react when the announcement of merger and acquisition was announced. This probability model could be a benchmark for the company's decision whether to get a deal with the process or to drop it. The probability model is set as follows: for further details on how to get the formula, the readers will be referred directly to Kasper (2008). Begin from the traditional valuation of discounted cash flow model, that assuming there is only one possible outcome for the terminal value of the dividend during the holding period.

$$
P_{t}=\sum_{j=t+1}^{T} \frac{C F_{t}}{(!+k)^{j-T}}+\frac{P_{T}}{1+k^{T-t}}
$$

It is important to see what is actually the expected terminal value of having merger and acquisition process. Using only eq. (1) cannot describe what is the expected terminal value would be, since eq. (1) only calculated the cash flow of dividend after the process has done. To distinguish the terminal price from the traditional terminal price of the discounted cash flow model, there are some definitions in the probability model that will be given as follows (Kasper, 2008):

$$
p_{t}=\frac{P_{t}-V_{u_{t}}}{V_{m_{t}}-V_{u_{t}}}
$$

The term $p_{t}$ is the probability success during the offering period, and it measures the investor sentiment. $V_{\mathrm{u}}$ is for the market price when there is no offer or not succeed and called the unaffected price. $V_{m}$ is for the offering price, if the merger process is completed the acquired company will get the offering price, but if the merger is not completed, the acquired company will continue to receive the actual cash flow and the price will be the same as the unaffected price $V_{u}$.

$$
V_{u_{t}}=V_{u_{t-1}}\left(1+\beta E\left(r_{t}\right)+(1-\beta) r_{f}\right)
$$

This formula is actually the capital asset pricing model theory. $\beta$ is the sensitivity measurement of the stock price return, the market return, $\mathrm{rt}$ is the return of the market, and $r_{f}$ is the risk free rate. In this model the expectations of value change from the investor's perspective depend on the expectation of the process outcomes. During the holding period of merger and acquisition, the price will change and the market price will reflect the prospects between those two values.

\section{Methodology}

The methodology that we use here is given as follows:

- We used information that is available to the public for investor to get. The information that we use here is the announcement from the Regulator Committee of Business Providers (Komite Penyelenggara Pengawasan Usaha/KPPU) (1). Since 2009, Indonesia government taking some regulation, in order to avoid monopoly action from the companies that have a plan for merger and acquisition. The regulatory mandate is given to KPPU. KPPU will thoroughly make some valuation 
whether the companies tend to have a monopoly action or not, than they will announce to public if they have any objections or not. Beside that we also find other information that support the news from KPPU, and also information about the companies who have also plan to merge or acquire but have not yet report to the KPPU. The news comes from public newspaper such as Jakarta Post (2), Viva News (3), Reuters mobile (4) etc. The news that we used are only available from 2009-2012.

- Using the data of the target company that listed in Indonesia stock exchange. Data is taken from ICMD (2009-2012) and website of yahoo finance ${ }^{(5)}$.

- $\quad$ Finding index price of Indonesia Stock Market (JKSE) during the announcement time.

- Searching for the availability of the offering price $V_{m}$.

- Calculating the return of the target companies and the return of the market during the announcement, following finding the unexpected price of $V_{u}$ by using the risk free rate from Central Bank of Indonesia (BI rate) and using the beta of the stock one year before the first announcement of the process. After that, calculating the probability model of investor sentiment.

Data: Samples are taken from period 2009-2012, based on the existing of KPPU. The chosen samples only limited with the next conditions:

- Choosing only the target companies which are listed in the Jakarta Stock Exchange and already listed at least for one year

- The offering price and the end price should be cleared stated in the news.

- The target companies are offered only with one price from the buying companies.

With these conditions, we get only four from seven samples that can be measured for investor sentiment during merger and acquisition process. The other three samples are rejected, since they did not fit to the conditions. Those chosen samples are:

- $\quad$ Merger planning of PT. Bakrie Telecom, TBK (BTEL.JK) by PT. Telkom, Tbk. The planning is failed. PT. Bakrie Telecom, TBK asked for offering price on June 8, 2010, with offering price Rp. 250 per share, $47 \%$ premium from the price, Rp $170^{(4)}$. End offering on January 13, 2011(8).

- Acquisition of PT Sorini Agro Asia Corporindo, Tbk (SOBI.JK) by PT Cargill Foods Indonesia; on January 27, 2011. The process is succeed. PT. Cargill Foods began their offering on December 15, 2010, with offering price at Rp. 3500 per-share (3). They had a deal on Januari 27, 2011 with deal price of Rp. 3500 per share.

- Acquisition of PT. Bank Agroniaga, Tbk (AGRO.JK) by PT Bank Rakyat Indonesia (Persero) on March 13,2011 . The offering is succeed. PT. Bank Rakyat Indonesia began to announce for acquiring on 24 Februari 2010. No price offering was mentioned. Therefore, for the offering price we assume the price of the first day, when the offering was announced Rp. 140 per share. They agree to take over the shares on Augustus 19, 2010, and had a deal on March 3, 2011.

- Acquisition of PT Berau Coal Energy Tbk., (BRAU.JK) by Vallar Investments UK Limited. On April 7, 2011. Vallar investments had offered for acquisition on November 16, 2010(6), at this point price of BRAU going down $1.92 \%$ equal to Rp. 510. It means that the offering price will be $5.9 \%$ more from the price starting point. On December 12, 2010, Vallar buys 26.175.000.000 shares for value of Rp 14.134.500.000.000 with end offer price Rp 540 per share.

\section{Results and Discussion}

We are going to give results and discuss it for every target companies according to the data.

- The trend of the investor sentiment for the merger of Bakrie Telecom, Tbk (BTEL) and PT. Telkom Tbk, showed that the sentiment is increasing at some point that trend line following the trend of the price, figure (1) and the market, figure (2). From the beginning of this process, Indonesian government gave his support for this two big telecom companies to merge (2). We can see here the enthusiasm of investor is positive when hearing the support of the Government. Then, in the middle of October 2010 the labor union of PT. Telkom, Tbk did not approve for this planning, and ended up with demonstration act in November 30, 2010 (http://www.politikindonesia.com) in front of the President Palace. The trend of the investor sentiment had been declined since then, it went down 
since the Indonesian President forbid this planning. This merger process was declined in January 13, 2011.

- Acquisition of PT Sorini Agro Asia Corporindo, Tbk (SOBI.JK) by PT Cargill Foods Indonesia is succeeded on January 27, 2011.

- From figure (3) and (4), we see that the sentiment of investor was increasing when the planning is announced. However, in the beginning of June, the sentiment was going down, and we do not have any explanation why this is happened. However, the acquisition planning is still going on and it is succeeded.

- Acquisition of PT. Bank Agroniaga, Tbk (AGRO.JK) by PT Bank Rakyat Indonesia (Persero) succeeds on March 13, 2011.

- From figure (5) and (6) we can see the sentiment of investor was also tend to increase after some period of time compare to the stock price and the market. The acquisition planning is succeeded.

- Acquisition of PT Berau Coal Energy Tbk., (BRAU.JK) by Vallar Investments UK Limited. From figure (7) and (8) we can see the sentiment of investor was also tend to increase after some period of time compare to the stock price and the market. The acquisition planning is succeeded.

Figure 1: Bakrie Telecom (BTEL.JK) against its investor sentiment
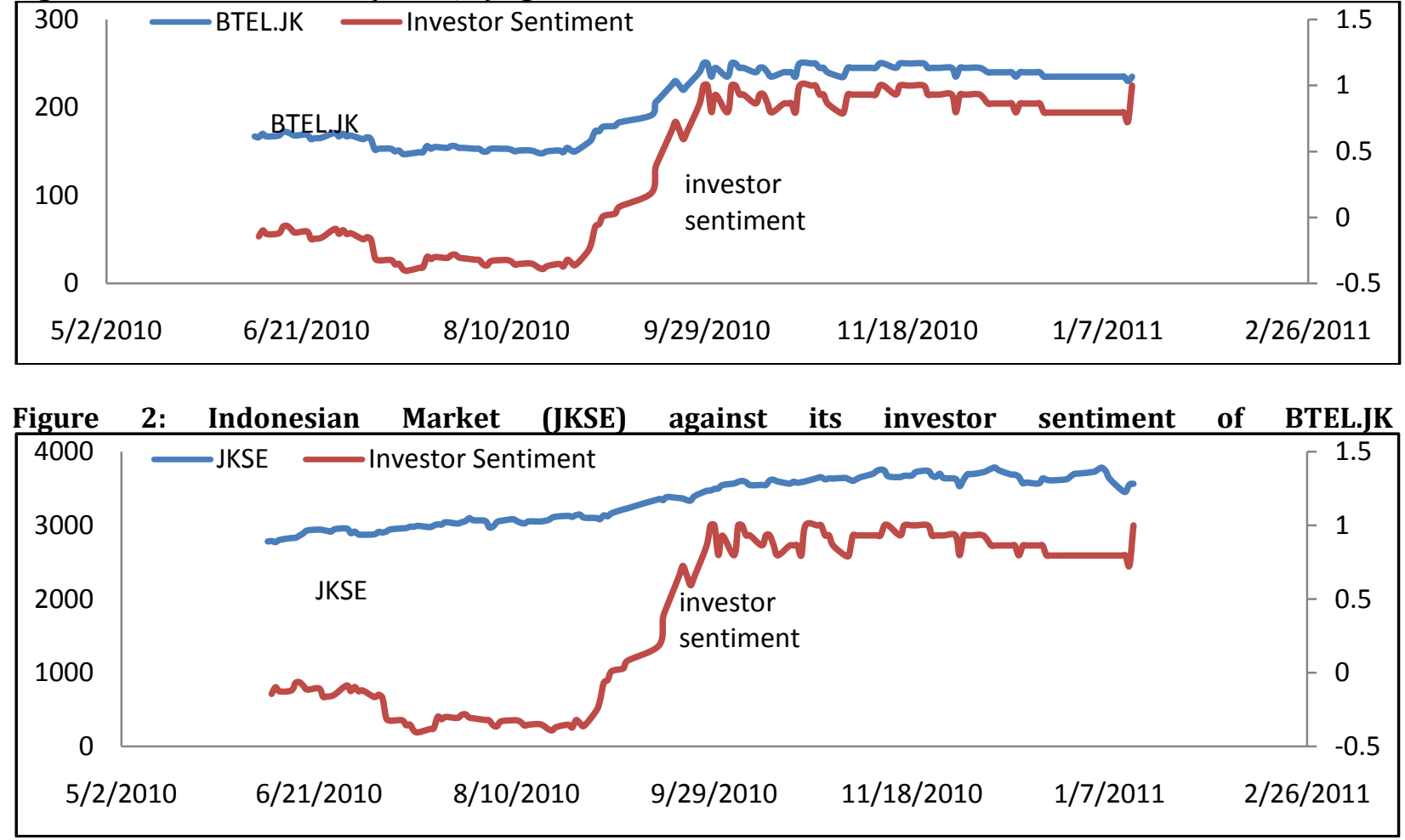

\section{Conclusion}

A simple probability model of Investor sentiment that is modeled by Kasper (2008), shows that from period 2009-2012 in Indonesia during the merger and acquisition process the sentiment is going to increase, after the first announcement. We can see that the model can track the day-to-day changes in the sentiment separate from the market movement. Seems also that the investor has interest in this process and tend to enthusiastic to the process. Using this enthusiasm the buyer and the target companies should look, and consider a strategy whether to sell /buy it or hold it.

Figure 3: PT Sorini Agro Asia Corporindo, Tbk (SOBI.JK) against its investor sentiment 


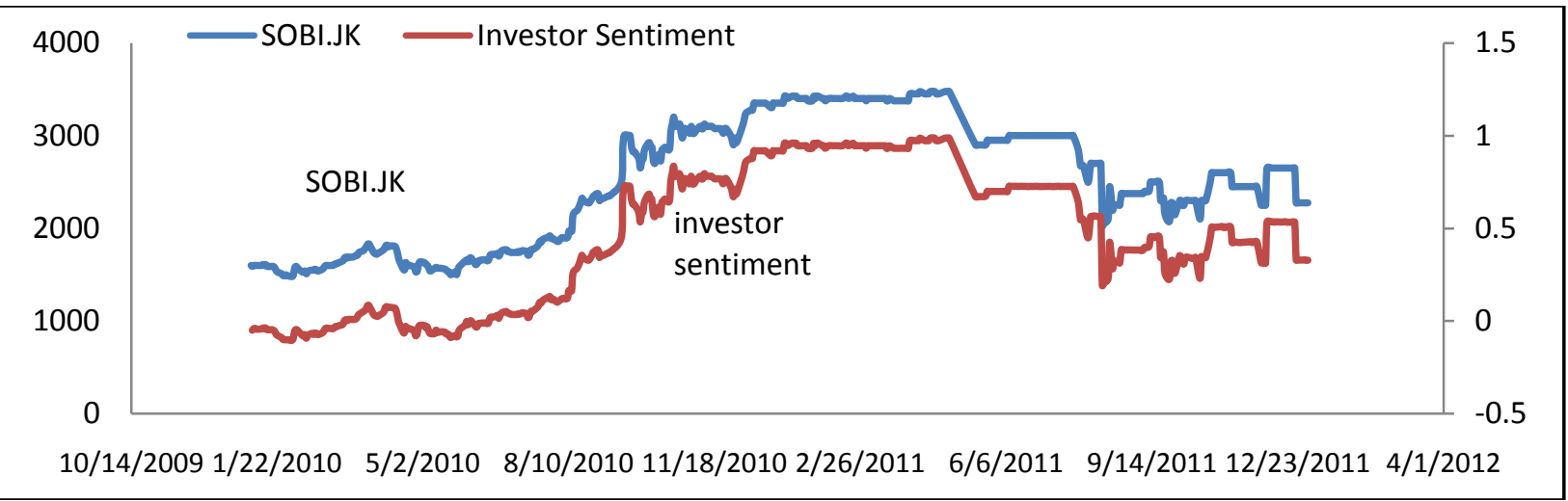

Figure 4: Indonesian Market (JKSE) against its investor sentiment of SOBI.JK

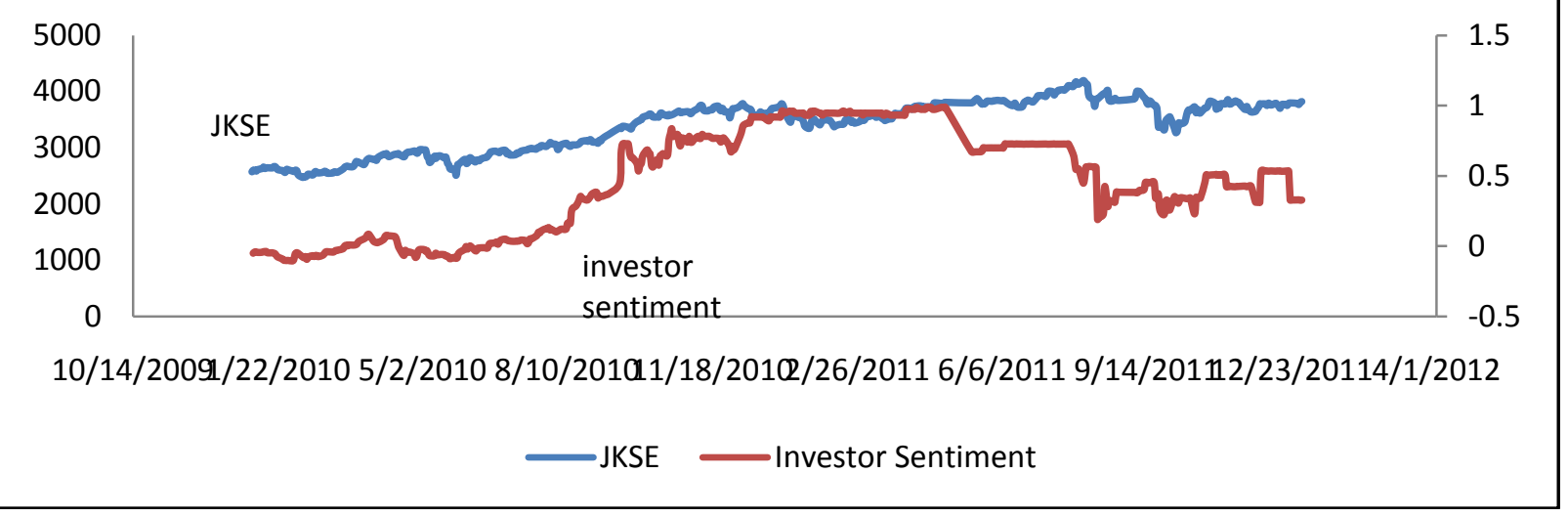

Recommendation: There so much to be more explore in this behavior of investor during the process of merger and acquisition. For further research, there should be more data of the merger and acquisition process to be used and conduct testable hypotheses between the successful and the unsuccessful process of merger and acquisition, to anticipate the process outcome.

Figure 5: PT. Bank Agroniaga, Tbk (AGRO.JK) against its investor sentiment

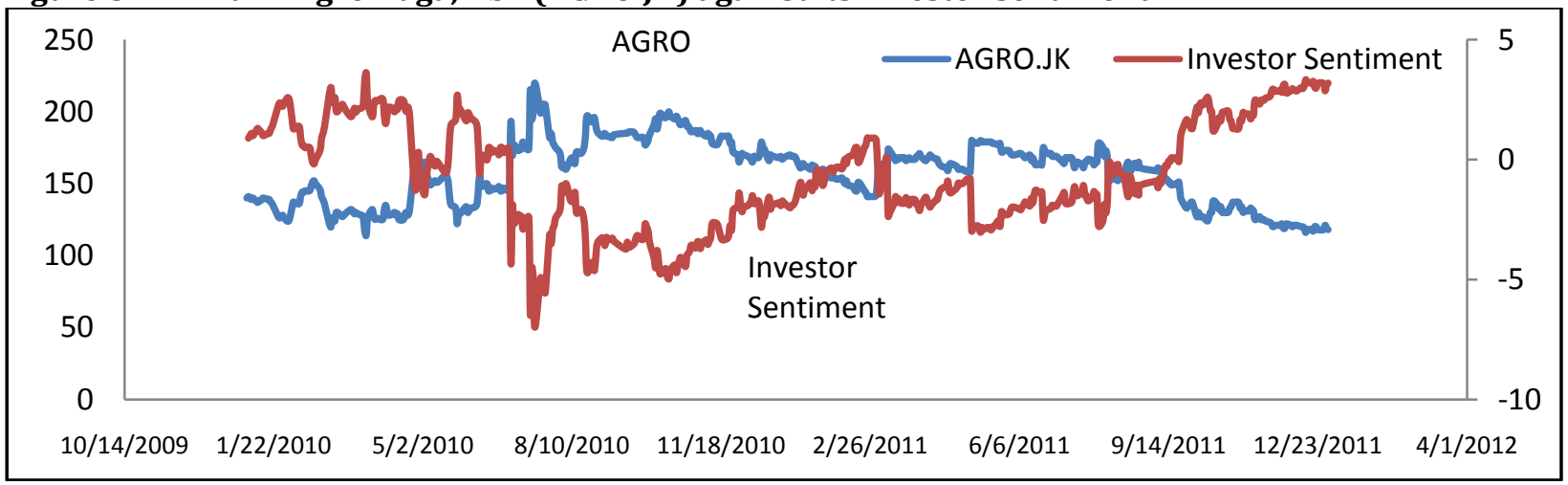

Figure 6: Indonesian Market (JKSE) against its investor sentiment of AGRO.JK 


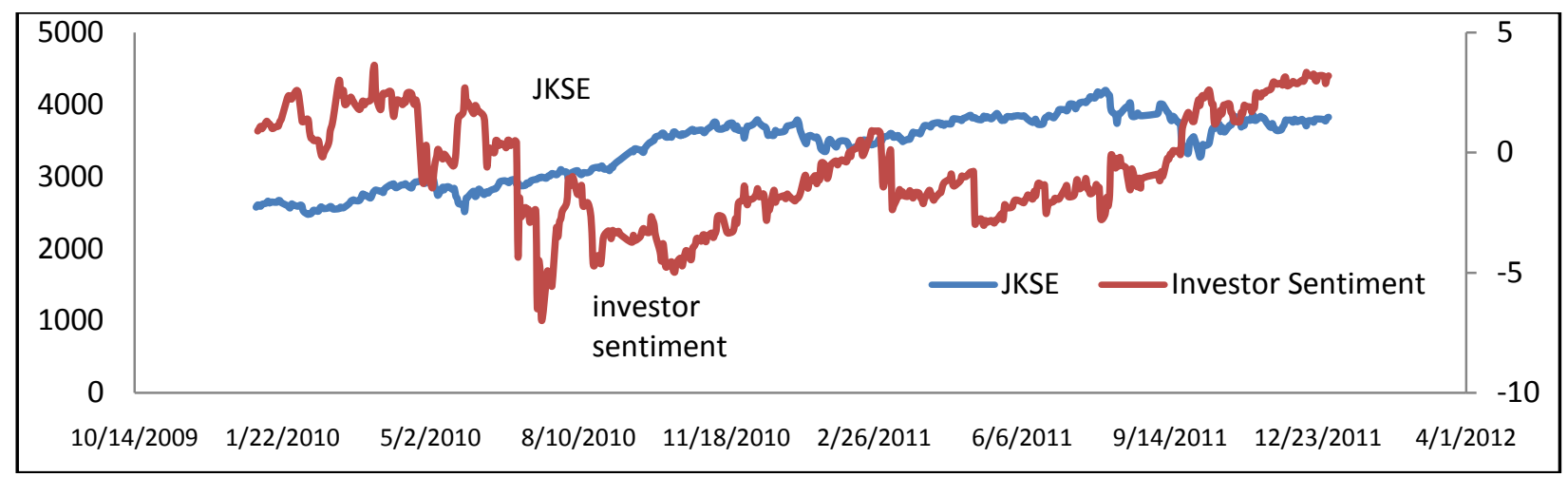

Figure 7: PT Berau Coal Energy Tbk., (BRAU.JK) against its investor sentiment

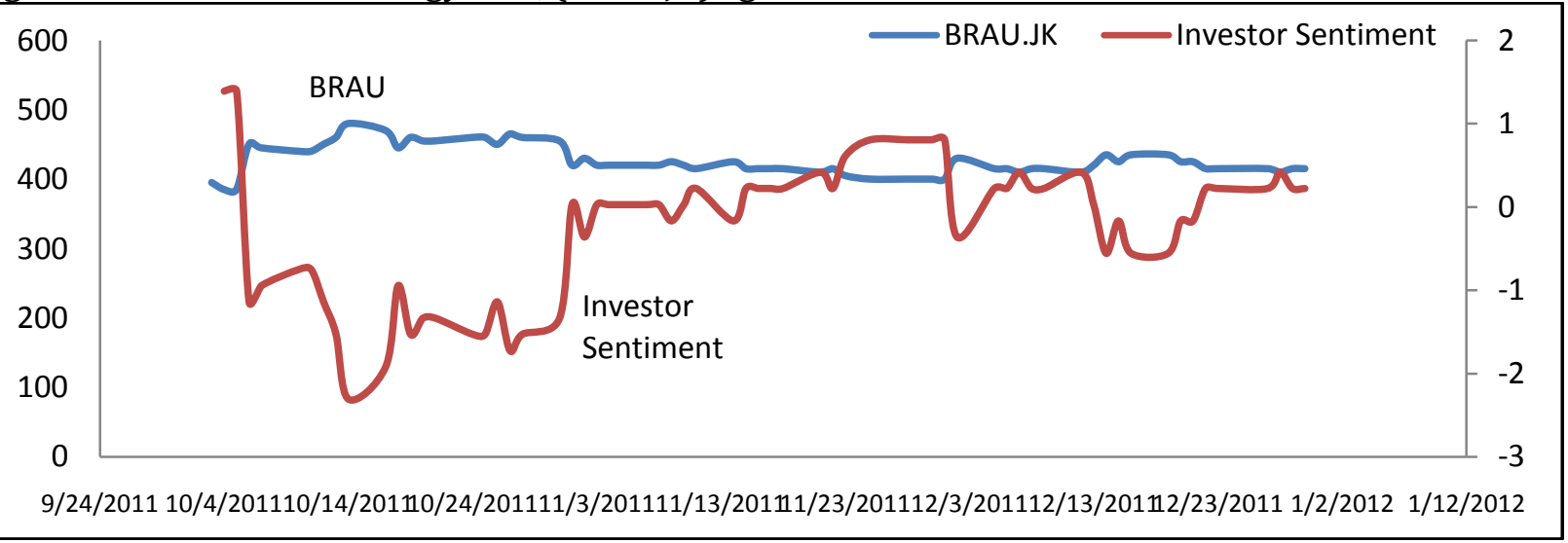

Figure 8: Indonesian Market (JKSE) against its investor sentiment of BRAU.JK

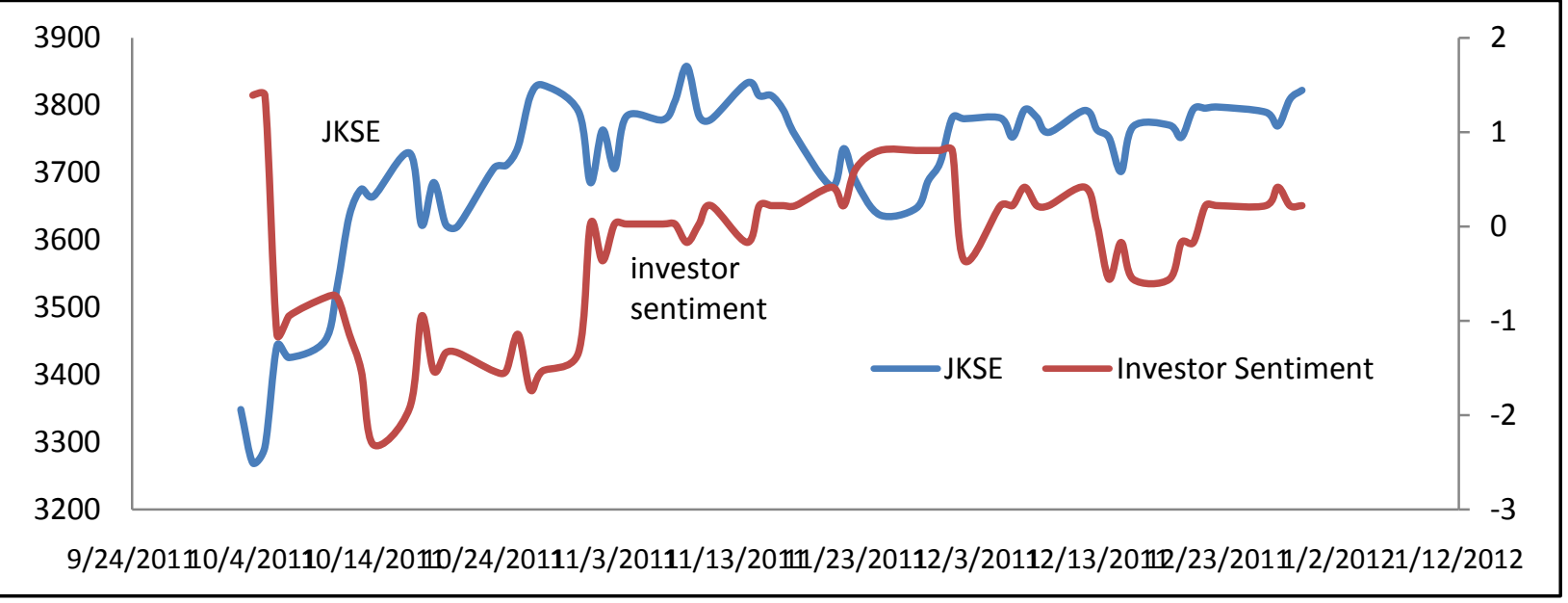

\section{References}

Baker, M. \& Wurgler, J. (2006). Investor sentiment and the cross-section of stock returns. Journal of Finance, 61, 1645-1680.

Baker, M. \& Wurgler, J. (2007). Investor sentiment and the stock market. Journal of Economic Perspectives, 21, 129-151.

Barberis, N., Shleifer, A. \& Vishny, R. (1998). A Model of Investor Sentiment, Affect Stock Market Crises? Evidence from Panel Data, halshs-00534754, version 1 - 10 Nov 2010

Black, F. (1986). Noise. Journal of Finance, 41, 529-543. 
Bernanke, B. S. \& Kuttner, K. N. (2005). What Explains the Stock Market's Reaction to Federal Reserve Policy? The Journal of Finance, 60(3), 1221-1257.

Brown, G. W. \& Cliff, M. T. (2004). Investor sentiment and the near-term stock market. Journal of Empirical Finance, 11, 1-27.

Brown, G. W. \& Cliff, M. T. (2005). Investor Sentiment and Asset Valuation. Journal of Business, 78, forthcoming.

Daniel, K., Hirshleifer, D. \& Subrahmanyam, A. (1998). Investor Psychology and Security Market Under and Overreactions. Journal of Finance, 53, 1839-1886.

De Long, J. B., Shleifer, A., Summers, L. H. \& Waldmann, R. J. (1990). Noise Trader Risk in Financial Markets. Journal of Political Economy, 98, 703-738.

Kasper, L. J. (2008). Measuring Investor Sentiment in Mergers and Acquisitions, Valuation Strategies: Nov/Dec 2008; 12, 2; ABI/INFORM Complete, pg. 4

Kumar, A. \& Lee, C. M. C. (2006). Retail investor sentiment and return comovements. Journal of Finance, 61, 2451-2486.

Kurov, A. (2010). Investor Sentiment and The Stock Market's Reaction to Monetary Policy. Journal of Banking and Finance, 34, 139-149

Lee, C., Shleifer, A. \& Thaler, R. (1991). Investor sentiment and the closed end fund puzzle. Journal of Finance, $46,75-109$.

Neal, R. \& Wheatley, S. M. (1998). Do measures of investor sentiment predict returns? Journal of Financial and Quantitative Analysis, 33, 523-47.

Solt, M. E. \& Statman, M. (1988). How useful is the sentiment index? Financial Analysts Journal, 3, 45-55. 